\title{
Photopsia revealing a retinocytoma
}

\author{
Cristina Santos, Mário Ramalho, Inês Coutinho, Susana Teixeira
}

Opthalmology Department, Hospital Prof. Doutor Fernando da Fonseca, Amadora, Portugal

\section{Correspondence to} Dr Cristina Santos, cristinamsantos@gmail.com

Accepted 20 July 2015

\section{DESCRIPTION}

A 28-year-old healthy man presented to our ophthalmology emergency department with a 6-month history of photopsia of his right eye. He had a best corrected distance visual acuity of 1.0 in his right eye and 1.2 in his left eye. Anterior segment examination at the slit lamp was unremarkable. On fundoscopy, the posterior pole in his right eye was unremarkable (figure 1), but a white voluminous subretinal lesion surrounded by an area of pigment epithelium atrophy and hypertrophy was observed on the inferior quadrants. Its appearance was very similar to type 1 (calcified remnant) retinoblastoma regression (figure 2). Ocular ultrasound revealed a mass with high reflectivity with an apical height of $4 \mathrm{~mm}$ and $6 \mathrm{~mm}$ at its largest basal dimension. CT scan confirmed the calcified nature of the tumour (figure 3). Presumptive diagnosis of retinocytoma

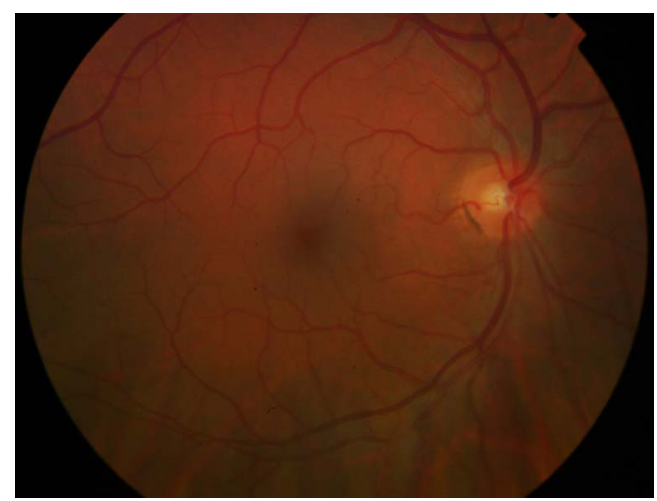

Figure 1 Unremarkable posterior pole retinography of the right eye.

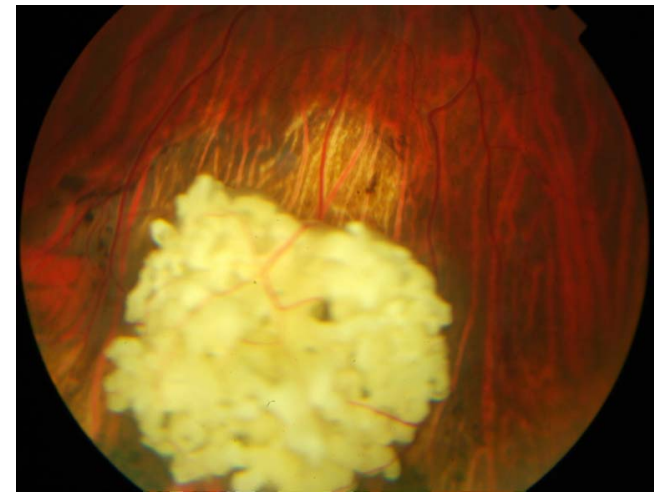

Figure 2 Inferior periphery retinography revealing a large, white subretinal mass associated with atrophy of the pigment epithelium.

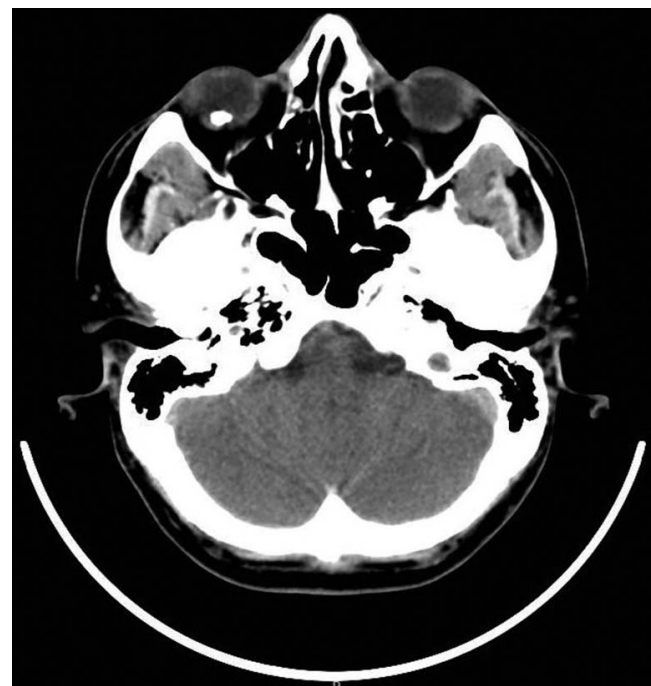

Figure 3 Cranial CT scan showing intraocular calcification.

was established. Revision of the literature showed that although retinocytoma does not require treatment, surveillance is crucial since there is an estimated malignant transformation in $4-12 \%$ of patients. ${ }^{12}$ Furthermore, it carries the same genetic implications as that of a retinoblastoma. ${ }^{12}$ In light of these findings, the patient was subject to genetic testing and siblings were subject to ophthalmological examination.

\section{Learning points}

- Retinocytoma is a benign lesion with risk of malignant transformation.

- Retinocytoma carries the same genetic implications as that of a retinoblastoma.

Acknowledgements The authors would like to acknowledge Dr João Cabral and Dr Francis Munier for help in confirming the diagnosis.

Competing interests None declared.

Patient consent Obtained.

Provenance and peer review Not commissioned; externally peer reviewed.

\section{REFERENCES}

1 Abouzeid H, Balmer A, Moulin AP, et al. Phenotypic variability of retinocytomas:preregression and postregression growth patterns. Br J Ophthalmol 2012;96:884-9.

2 Singh $A D$, Santos $C M$, Shields $C L$, et al. Observations on 17 patients with retinocytoma. Arch Ophthalmol 2000;118:199-205. 
Copyright 2015 BMJ Publishing Group. All rights reserved. For permission to reuse any of this content visit http://group.bmj.com/group/rights-licensing/permissions.

BMJ Case Report Fellows may re-use this article for personal use and teaching without any further permission.

Become a Fellow of BMJ Case Reports today and you can:

- Submit as many cases as you like

- Enjoy fast sympathetic peer review and rapid publication of accepted articles

- Access all the published articles

- Re-use any of the published material for personal use and teaching without further permission

For information on Institutional Fellowships contact consortiasales@bmjgroup.com

Visit casereports.bmj.com for more articles like this and to become a Fellow 